\title{
OBITUARY
}

\author{
In Memory of PhDr. Viktor Krupa, DrSC.
}

On 14 February 2021 our precious colleague and friend Dr Viktor Krupa, an outstanding Orientalist, linguist, translator, and author of travel books, the founder of Oceanic and Polynesian studies in Slovakia, and one of the founders of Japanese studies at the Department of Oriental Studies of the Slovak Academy of Sciences and the Faculty of Arts, Comenius University passed away at the age 84. Viktor Krupa worked for the Department of Oriental Studies, which was renamed to the Institute of Oriental Studies in 2014, for forty-nine years. He spent this period working more than hard - doing research, popularizing science, translating, teaching, and organizing. In each of these areas he has achieved exceptional results, not only thanks to his talent but also thanks to his extraordinary diligence.

Viktor Krupa was born on 23 December in Nové Mesto nad Váhom. He graduated in Slovak and Russian from the Faculty of Arts at Comenius University in Bratislava in 1959, enriching the fields with his studies Stavové perfektum $v$ slovenčine [The "State" Perfect in Slovak] (1962) and K nekotorym problemam stradatelnogo zaloga soveršennogo vida v russkom jazyke [On Some Problems of the Passive Voice of the Perfective Aspect in the Russian Language] (1962). However, it was Oriental Studies which enchanted him. In 1961 he joined the Department of Oriental Studies of the Slovak Academy of Sciences and soon became a highly regarded expert on Polynesian languages, especially Maori, Marquesan, and Hawaiian, as well as Austronesian languages, in particular Indonesian and Malay, which he had studied at the University of Auckland in New Zealand in 1965 - 1966. In 1966 he published a monograph entitled Morpheme and Word in Maori with a prestigious Dutch publisher Mouton and Co. In 1965 he defended it as his doctoral thesis. The monograph was followed by two more books on Maori, both published in Moscow: Jazyk maori in 1967 and The Maori Language in 1968. In the coming years he published his book Polynesian Languages. A Survey of Research with the prestigious publisher Mouton in Hague (1973) and Polinezijskije jazyki [Polynesian Languages] (1975) and Gavajskij jazyk [The Hawaiian Language] (1979) in Moscow again. As is evident, in the first two decades of his research activities Viktor Krupa made full use of his expertise in the linguistic issues of 
Asian and African Studies, Volume 30, Number 1, 2021

Polynesian languages, as well as of his ability to promptly translate it into book publications at high academic level. His success probably would not have been possible without research stays at the University of California in Berkeley in 1969, where he studied general linguistics, and at the University of Hawaii in Honolulu.

He also visited some countries he was interested in (not only) as a researcher in the next twenty years. He studied at the universities in Münster and Tübingen, thanks to the support from the Humboldt Foundation $(1970-1971)$, as well as in Japan (1983) or in Great Britain, Denmark, New Zealand (1988), and at the University of Australia in Canberra in 1990. Also in this period his research focused on Polynesian languages, culminating in the publication of his book The Polynesian Languages with Routledge and Kegan Paul Ltd in London in 1982. However, his other book publications from this period assume a slightly different character. They focus on broader issues of general linguistics, the philosophy of language, creativity in language and similar, all issues on the boundary between linguistics, literary science, and ethnography. Of course, they are very often connected with Oriental languages - Oceanic languages, Southeast Asian languages, as well as Japanese. The second two decades of Krupa's research activities opened with the monograph Jednota a variabilita jazyka. Systémový pristup a tzv. exotické jazyky [The Unity and Variability of Language. A Systemic Approach and so called 'Exotic' Languages], which was published in Bratislava in 1980 and which earned him a degree of DrSc. The monograph draws on his broad expertise in Oriental studies and confronts materials from known European languages with materials from 'exotic' languages, such as Southeast Asian and Oceanic languages. Krupa's admirable erudition is also reflected in the book Jazyky sveta [Languages of the World] from 1983, which he wrote together with his colleagues Jozef Genzor and Ladislav Drozdík. A similarly broad scope is also characteristic of his book Pisma sveta [Writing Systems of the World] (1989), authored with Jozef Genzor again. In this period Viktor Krupa focused, besides other things, on the metaphor. The results of his research are summarized in his work Metafora na rozhrani vedeckých disciplin [Metaphor at the Crossroads of Scientific Disciplines] (1990), which represents, as its reviewers say, "the first attempt in the form of a monograph in the former Czechoslovakia at a concise analysis of the function of a metaphor as a means of creativity in language, with regards to poetry, mythology, academic terminology, etc." The author takes into account the interdisciplinary character of the metaphor although the focus of his research is on the language sphere. He uses Slovak, Japanese, Indonesian, and Polynesian languages as his primary material. In 1991 Viktor Krupa published another monograph entitled Jazyk - neznámy nástroj [Language - the Unknown Instrument], in which he explains different areas of the functioning of language, 
using his profound theoretical knowledge and practical experience from his own literary and translation activities. In 1996 the second supplemented and revised edition of his Jazyky sveta was published under the title Jazyky sveta v priestore a čase [Languages of the World in Space and Time]. These two decades conclude with his monograph Legendy a mýty Polynésie. Polynéská kosmogonie [The Legends and Myths of Polynesia. Polynesian Cosmogony] (1996), in which he sets Oceanic myths and Polynesian creation myths into a broader context of the traditional division of Oceania and the linguistic and cultural division of Polynesia.

Unfortunately, the last two decades of Viktor Krupa's admirable research activities were interrupted by a disease when the second decade was about to start. However, in the first decade of this period he managed to publish a broadly outlined cultural-anthropological monograph Národy juhovýchodnej Azie a Oceánie. 1. Národy ostrovnej juhovýchodnej Ázie (together with his daughter Martina Bucková) [The Peoples of Southeast Asia and Oceania. 1. Peoples of Insular Southeast Asia] (2003), which offers a general picture of the region's culture, languages, and history. This was followed by publications which display his interest in language politics especially in Asia with emphasis on the emancipation period: Jazyková politika a problémy komunikácie [Language Politics and Communication Issues] (2006 in cooperation with Ladislav Drozdík and Anna Rácová), in which he focuses on the multilingual societies in Malaysia, Indonesia, and in the Philippines, and on the issue of a uniting language. His research into linguistics was crowned with the publication Pohyby jazykov v čase a priestore od globalizácie k revitalizácii [Movements of Languages in Space and Time from Globalisation to Revitalisation] (2010), which represents a summary of the existing knowledge of the past and the present of numerous Polynesian islands, brings a new view of the changes in their cultures, of the issue of the future orientation of certain ethnic groups, and of the role of local languages.

Viktor Krupa's monographs attest to the immensely broad scope of his research activities. However, they are but a few pieces (however significant) in the colourful mosaic of his research. This mosaic would not be complete without his research articles focused on different aspects of general linguistics or problems of particular Polynesian languages. Some of them were produced in cooperation with his colleague Gabriel Altamann: for example, "On Relations of Structure and Inventory in Linguistic Systems" or "Relations between Typological Indices"; others in cooperation with his good friend Slavomír Ondrejovič, such as "Jazyk i vozmožnosti jego regulirovania" [Language and the Possibilities of Its Regulation], "Jazyk ako fenomén" [Language as a Phenomenon], "Jazykové mýty" [Language Myths], "Jazykové mýty a ich poslanie" [Language Myths and Their Function]. Several of Krupa's studies 
Asian and African Studies, Volume 30, Number 1, 2021

were published in prestigious foreign academic journals: for example, "On the Category of Possession in Maori" in Bulletin of the School of Oriental and African Studies in London, "The Phonemic Structure of Bi-Vocalic Morphemic Forms in Oceanic Languages" in Journal of the Polynesian Society, "A Typological Comparison of Polynesian Phonemic Systems" in Beiträge zur Linguistik und Informationsverarbeitung, "The Phonotactic Structure of the Morph in Polynesian Languages" and "Linearity of Sentence and Typology" in Language in Baltimore, "Linguistic Trends in Australia" in Archiv orientální, "Moon in the Writing of Easter Island" and "Syntax of Verbal Nouns in Marquesan" in Oceanic Linguistics, "Problems of Maori Lexicology" in Glottometrika in Bochum. Viktor Krupa was also an assiduous contributor to the Slovak journal Asian and African Studies, which he helped establish in which he worked as the editor-in-chief in $1992-1998$, as well as to Jazykovedný časopis published by the Ludovít Štúr Institute of Linguistics, where he had got his $\mathrm{PhD}$ and where he had liked to return to until his retirement. His well-researched and original studies were always welcome in Slovenský národopis, Historický časopis, Slovenská reč, Kultúra slova, Human Affairs (where he had worked as the editor-in-chief in 1991 - 1998), and in other journals. Many were also published in essay collections and books.

Krupa's studies, even more obviously than his monographs, reflect the wide range of his research interests. They are focused, for example, on particular problems of morphology, syntax, and the linguistic categories of Polynesian languages, different typological answers, the problem of the category of system in linguistics from the point of view of philosophy, the variability and reflexive character of language, the relationship between language, thinking, and reality, the questions of development and 'primitive' languages, the sources and functions of vagueness in language, the contemporary language situation in Oceania and the language politics in Southeast Asia and Polynesia, the problem of national and cultural identity in Polynesia, and many others. Being a prolific translator, Krupa has also dealt with questions related to translation. He has written papers on translation and difference in the literary structure of a sentence, hierarchical non-equivalence in translation, translation and word order, the structural non-equivalence of languages and translation problems, and similar. It may have been translation which provoked his interest in the metaphor, which is reflected not only in the above mentioned book, but also in numerous studies.

Enumerating everything that Dr Krupa has done within his research activities would take up a lot of room and time. After all, the diversity and breadth of these are reflected in his rich bibliography.

However, Dr Viktor Krupa was not only an excellent researcher, but also an outstanding and gifted storyteller, which is attested to by his works of fiction. 
He was particularly prolific in this area in the 1970s and 1980s when he wrote eight books. He described his impressions from his first visit to New Zealand in Za siedmimi morami [Beyond the Seven Sees] (1970). This book was followed by a range of books describing the voyages of the Europeans in the Pacific: the story of the French expedition to the Pacific Ocean at the end of the 18th century Záhadný prípad kapitána Lapérousa [The Mysterious Case of Captain Lapérouse] (1975), Kostrovom neznámych pokladov [To the Islands of Unknown Treasures] (1978), a book describing an exploratory voyage to the Solomon Islands, Hladanie posledného raja [The Search for the Last Paradise] (1978), including a selection of the most remarkable engravings related to the voyages of five significant explorers, Stroskotanci zlode Wager [Shipwreck Survivors from the Wager] (1980), Malebná cesta okolo sveta [Picturesque Journey around the World] (1980), and Cesty kapitána Quirosa [Journeys of Captain Quiros] (1982). The eighties concluded with Krupa's popular scientific book Polynézania [The Polynesians, 1988], which strives to take a sober view of Polynesia's life style, culture, and history and at least partially rectify the way this region is portrayed by sensationalist authors.

Another important area in which Viktor Krupa's diverse personality has shown itself is his translation activity. Krupa is no doubt one of the best-known, most significant, and sought-after Slovak translators. His competitive advantage rests in his good knowledge of the source (often 'exotic') language, nice Slovak, and awareness of numerous translation pitfalls, which is, after all, attested to by the above mentioned studies on translation. Thanks to dozens of his translations, Slovak readers got access not only to the literatures and cultures of the countries of the Orient, but also to many works of world literature, which he has translated from English. His first translations and retellings of works from Oriental languages include children's books, for example, Maori tales Obrova stupaj [The Giant's Footprint] (1965, 1975), Japanese tales Chlapec zbroskyne [The Boy from the Peach] (1969), Polynesian tales Rozprávky $z$ nefritových hôr [Tales from the Nephrite Mountains] (1973), retellings of Hawaiian legends Pribehy havajských králov [Stories of Hawaiian Kings] (1979). He can also boast of having translated a selection of old Japanese poetry under the title Kvety $v$ ln [Flowers of Waves] (1985). Krupa's knowledge of the mythology of Pacific areas is available to Slovak readers in his translations Polynézske mýty [Polynesian Myths] (1973) and Havajské mýty [Hawaiian Myths] (1982). Japanese myths included Kodžiki. Japonské mýty [Kojiki. Japanese Myths] (1979). His numerous translations from Oriental languages were published in translation collections or magazines and journals.

Viktor Krupa has also done a lot of translations from English. Many of them are related to the Orient's life and culture and authored by prominent representatives of world literature. They include R. C. Suggs's Záhady 
Asian and African Studies, Volume 30, Number 1, 2021

polynézskych ostrovov [The Island Civilizations of Polynesia] (1966), Ch. A. Borden's Plavil sa s kapitánom Cookom [He Sailed with Captain Cook] (1970), Yasunari Kawabata's Spiace krásavice [The House of the Sleeping Beauties], Wilhelm Ziehr's Peklo v raji. Objavenie a zánik tichomorských kultúr [Hell in Paradise] (1984), James Clavell's Tajpan. Román o Hongkongu [Tai-Pan] (1987), Herman Melville's Omu (1987), Rudyard Kipling's Vojna sahibov [A Sahibs' War] (1989), Louis Bromfield's Noc v Bombaji [Night in Bombay] (1991), Richard Tames's Objavovanie Japonska [Exploration into Japan] (1996), and Leo Deuel's Odkazy vekov. Quite a few works that Viktor Krupa has translated are not about the Orient. He was the first to translate Tolkien's Hobbit $(1973,2$ nd ed. 1994) into Slovak. His translation of Jonathan Swift's Gulliver's Travels is also remarkable. He can also boast of having translated Edward Gibbon, Joseph Conrad, Daniel Defoe, Johan Huizinga, Arthur Miller, Mario Puzo, Erich Segal, Peter Carey, and others. However, he has also translated non-fiction, for example, Jakobson's "Lingvistika a poetika" and "Tajnaja služba Konštantína Filozofa a d'alší rozvoj staroslovanskej poézie" published in a selection from Jakobson's Lingivstická poetika [Linguistic Poetics] (1991) or Steven Pinker's Slová a pravidlá [Words and Rules] (2003), just to name a few. Slovak publishers and the Slovak Literary Fund have repeatedly shown recognition for his translation artistry and for the contribution of his translations to Slovak culture. His awards include, for example, the Ján Hollý Award for translation from Oriental languages, the Matej Bell Award, or the TROJRUŽA Award.

An overview of Viktor Krupa's professional activities would not be complete without his teaching activities. As has been mentioned, he co-funded the Department of Japanese Studies at the Faculty of Arts at Comenius University in Bratislava, where he also worked as a lecturer. He also spent many years teaching at the Institute of International Relations and Approximation of Law at Comenius University in Bratislava, at the Faculty of Political Sciences and International Relations of Matej Bel University in Banská Bystrica, and at the Faculty of Philosophy at Sts Cyril and Methodius University in Trnava.

Looking back at Viktor Krupa's activities, one must but wonder how he could manage. Was his day longer than the day of the other mortals? Besides his rich research, popularization, and translation activities, he also had to find time for his organizing work, especially when he was the director of the Institute of Oriental Studies in 1990 - 2002. In addition, he also worked on different committees and for different societies, such as the committee of the Slovak Academy of Sciences for linguistics and art studies, the committee of the Slovak Linguistic Society, he was a member of the Slovak Oriental Society, the Accreditation Commission of the Ministry of Education of the Slovak 
Republic, the Societas Linguistica Europea, the Scientific Committee of the Center for Theoretical Studies of Charles University in Prague and many others. $\mathrm{He}$ also sat on the editorial boards of several journals. In 2003 he became a full member of the Learned Society of the Slovak Academy of Sciences. His extraordinary contribution to Slovak research has also been awarded by the Presidium of the Slovak Academy of Sciences. He is the recipient of the Gold Plaque of Ludovít Štúr and the Gold Medal of the Slovak Academy of Sciences.

In this short contribution I have tried to point to some significant aspects of Viktor Krupa's working life. However, any picture of a person's life and personality would not be complete if we talked only about his work and achievements however remarkable they are. I would like to emphasize his immense talent, wisdom, diligence, friendliness, humaneness, and especially his modesty. During our common years at the Institute of Oriental Studies I never noticed Viktor Krupa elbowing his way to the foreground and drawing people's attention to his person and work that he had done. Great people are usually modest.

We honour his memory.

Anna Rácová

\section{Remembering Our Professor Ján Pauliny, the Leading Slovak Arabist}

It was not long ago that I was preparing a speech on the occasion of the ceremony for the presentation of the special volume (Arabic and Islamic Studies in Honour of Ján Pauliny) to our beloved and respected Professor Ján Pauliny, the most knowledgeable authority on Arabic literature, medieval historiography, and Islam in Slovakia. However, I had to modify the speech on the spot since Professor Pauliny, despite his previous reassurances, was unexpectedly unable to attend the ceremony owing to his deteriorating health. We all sincerely hoped that this situation was only temporary and that he would be sharing with us his vast scholarly knowledge for many years to come. Unfortunately, despite occasional improvements in his health, he finally passed away at the age of 81 on the 25th of January 2021. Yet, his passing was still a 
Asian and African Studies, Volume 30, Number 1, 2021

shock. It was painful to realize that these prolific and skilful hands, that had written and translated thousands pages of Arabic texts over fifty-five years, had surrendered the pen at last. This sad news was even more painful to bear since he left us in the middle of the terrible corona crisis, which did not allow us to accompany him on his final journey.

Death is overwhelming to the living. It prompts us to go back in time and reflect. I was fortunate enough to have worked side by side with Professor Pauliny for more than 15 years. And it was a truly invaluable experience to observe directly the methods of his scholarly work and pedagogy, his enthusiasm when something turned out well, his good-natured attitude to students, his sharp wit and his special gift for the exact assessment of important and unimportant tasks. The important ones had to be carried out without haste and with the utmost attention and dedication, and the others, mostly routine matters, had to be handled with great efficiency without wasting precious time. Most engagingly, Pauliny would speak not only about various avenues of research in the field of Arabic studies and his personal experiences during his fellowships abroad but also about his beloved family.

Ján Pauliny was born in Martin on 4 June 1939 into a family of intellectuals. His father, Professor Eugen Pauliny, was a highly respected Slovakist; his mother had graduated in French and Latin, and had studied both in Slovakia and France. An intellectual career and a talent for foreign languages were thus part of his birthright. After attending secondary school in Bratislava, he went to the Faculty of Arts of Comenius University, where he started studying Slovak language and literature in combination with Arabic.

In the following years, he opted to study at the Charles University in Prague where Oriental studies had a much longer scholarly tradition and where, in addition to Arabic, he studied English language and literature. Among his teachers were well-known Czech Arabists, especially Karel Petráček and Felix Tauer, the translator of the Thousand and One Nights into the Czech language. These scholars had a profound impact on Pauliny's further professional development.

In 1961 Pauliny received his Master's degree and was immediately offered a position at Professor Ján Bakoš’s Semitic Seminar at Comenius University in Bratislava. Similarly, his academic career seemed to progress quickly. In 1969 he completed his dissertation (al-Kis $\bar{a}^{\prime} \bar{l}$ : Kitāb qișas al-anbiya $\bar{a}^{\prime}$ ) and in 1975 his habilitation, entitled Zwei Beiträge zur Kenntnis der Arabischer Volksliteratur des Mittelalters: Zur Role der qușsāș, al-Kisā 'ìs Werk Kitāb 'adjā'ib al-malakūt [Two Contributions to the Understanding of Arabic Popular Literature: alKisā '̂̀'s Work Kitāb 'adjā'ib al-malakūt]. However, for political reasons, it was only after 26 years of academic work that, in 1987, he was finally awarded the position of associate professor (docent). 
After the revolution in 1989, the political situation in the country changed, and it was possible to travel to Western countries. Pauliny also started taking part in conferences and giving lectures (in 1991 at the Hebrew University of Jerusalem; in 1993 at the Université de Toulouse II - Le Mirail; in 1993, 1995 and 1996 at the Universität Heidelberg; in 1996 at Yale University and in 1996 at the Atlantic University of Florida). In addition to this, from 1991 to 1996 he was a regular Visiting Professor at the Oriental Institute at the University of Vienna, where he taught a course on Arabic popular literature.

After the retirement of Ladislav Drozdík (who was the successor of Ján Bakoš, the founder of the Semitic Seminar) in 1995, Pauliny played a decisive role in the formation of Arabic literary studies in Slovakia. He became the head of the Department of Classical and Semitic Philology (the name of the department since 1976), and in 1997 he was inaugurated as full professor in Arabic Language and Culture. In addition to that position, he had a profound impact on the faculty's academic life, serving as its dean from 1994 to 1998.

Pauliny's research has been mainly associated with Arabic profane and religious popular literature: writings mainly preserved in manuscripts or in early printed editions, a subject that at that time had received little attention. This area of Arabic studies influenced his whole academic career and became the dominant feature of his research from then on. In the course of his academic career he wrote more than forty scientific articles that were published worldwide but mainly in the faculty's journal, Graecolatina et Orientalia, which he cofounded, and in Asian and African Studies published by the Slovak Academy of Sciences. The impact of his research can be demonstrated by the number of citations of his papers, which by 1997 had already reached 194 (154 of which were from abroad). Many of his books become classics in their own right, e.g. Abú al-Hasan al-Kisá'í: Kniha o počiatku a konci a rozprávania o prorokoch [A Book about the Beginning and the End of the World, and Stories about the Prophets], Bratislava, Veda 1980. His monograph, Arabské správy o Slovanoch 9. - 12. stor [Arabic Reports about the Slavic People from the 9th to the 12th Centuries], published in 1999, represents, by contrast, a valuable source on the history of medieval Central Europe. Pauliny also played a significant role in the inclusion of the Bashagic Collection of Islamic manuscripts in UNESCO's Memory of the World Programme in 1997.

Of course, the fact that the field of popular Arabic is also generally known to Slovak readers is in part due to his 25-year history of association with the translation of the Thousand and One Nights. This impressive eight-volume edition of Shahrazad's stories, illustrated by the most distinguished Slovak artists, was finally published in the years $2009-2011$ by the Ikar publishing house. His other valuable translations from Arabic literature include Ibn Ishāq's Život Muhammada, Posla Božieho [The Life of Muhammad, Messenger of 
God], from 1967, with a second enlarged edition in 2003, or Ibn Sīrīn's Muntakhab al-kalām fì tafsìr al-ahläm [A Concise Guide for the Interpretation of Dreams], in 2 volumes, from 1996.

It is no wonder that as early as 2003 Ján Pauliny was awarded the Ján Hollý Prize for literary translation. In 2011 he received a nomination for the Krištál'ové krídlo [Crystal Wing] for literature and a special prize of the Slovak Minister of Culture. In 2016 he obtained the Gold Medal of the Faculty of Arts at Comenius University and in 2019 the Great Silver Medal of Comenius University. In 2019 he obtained the Blahoslav Hečko Prize for his lifelong work.

It is difficult to bid farewell to Professor Ján Pauliny: a scholar, an author, a translator and a teacher who taught us to admire Arabic history and literature. His passing is a great loss for both Slovak and international scholarship. Our delightful memories of him - of many inspiring talks, dinners, lessons and personal conversations - will remain with us forever.

Zuzana Gažáková 